\title{
The Financial Reconstructions in Europe
}

\subsection{Two Schemes, One Aim: The Comparison of the AustrianandHungarian Reconstructions}

The Austrian and Hungarian financial reconstructions were the first of a score of similar plans drawn up by the League of Nations and carried out under its watchful eyes. These first two attempts, as we have seen, were successful in the short run. These triumphs had several important consequences. First, the League's prestige grew immensely in Central Europe and elsewhere. Secondly, the success paved the way for further initiatives in this field, and other countries applied for the same remedy that had worked in the case of Austria and Hungary. Thirdly, the know-how of technical details that had been worked out and put into practice in Central Europe provided the blueprint for the following attempts at restoring fiscal stability in other Eastern and Southern European countries. Fourthly, and in many ways the most important, the initial success achieved in these two countries, helped enormously the German reconstruction attempt that came to be known as the Dawes Plan in late 1924. Although the first two programs shared much in common, there were many smaller or sometimes more significant discrepancies.

A comparison of these first two reconstructions programs is warranted. Since both schemes were claimed to have achieved the same goal, namely to create a stable currency, to stop the budget deficit, and to have an independent national bank, they were almost identical. At first glance indeed both programs showed the same features, but there were several differences, most of them not major, but significant enough to call attention to them. It is logical to first list what was conformable between the two rehabilitation efforts. ${ }^{964}$

The most important feature of both cases was that it was undertaken by the League of Nations. This fact alone defined certain aspects. Its role was crucial in creating the international collaboration necessary for the reconstruction efforts to occur. Neither Austria nor Hungary was in a situation to seriously initiate such an effort-without a benevolent supporter these countries had no real hope to bring their financial chaos to a halt. Both tried to achieve it through private channels first, but both failed. In the political landscape of

964 Since most of the data in this section is from earlier chapters of the dissertation, only those sources will be given that contain new information. 
Europe in the early 1920s, an ex-enemy country had no real expectation of being treated in a friendly or fair manner by its neighbors or the big powers of the continent. The one exception, the United States, showed no inclination to take responsibility for Europe. So, without the League of Nations no such plan could have been carried out. Therefore, it was a necessity that in both cases the League of Nations draw up the plan, thus giving credence to both reconstruction schemes.

Some further elements that were basically identical sprang from the League's fathering of the plans. The Protocols that were signed by the involved countries in both cases defined the major characteristics of the schemes: to set up a new central bank that was independent of the government; to stabilize the currency; to offer certain revenues as pledge for an international long-term loan; with the help of that loan to begin to carry out certain reforms and to achieve a balanced budget that would last; and to have a Commissioner-General take up his post in the given country to supervise and control the reforms being carried out and to function as a link between the host country and the League of Nations. In conformity with the Protocols, the two reconstruction plans could not be very different. All the points mentioned were closely followed and this defined the major similarity between the two programs. Even the countries that were willing to issue the long-term loan were almost the same in the two cases. Moreover, it was Montagu Norman's lead that ensured that the money conceived as essential was available. In addition, in both instances, the United States took a smaller-than-hoped part of the whole, signifying that American capital was interested in European financial issues only to a certain degree, Germany excluded. Naturally, the most important similarity was the triumphant accomplishment of both the Austrian and Hungarian reconstruction programs.

Although it is true that the aforementioned similarities outweigh the differences of both schemes, still, it is worth shedding light on some features that were different in these cases and try to answer why they were possible or necessary. A difference in the beginning was that Austria first applied to the Allied Powers and only after finding refusal there did it knock on the door of the League of Nations. The answer for that is that in 1921 and 1922 the League had not been able to assume the necessary prestige and leadership it wished to play. In many ways, it was the Austrian financial reconstruction that earned the organization the needed reputation, and in the case of Hungary it was almost evident that the help of the League was sought after attempts to secure private loans had failed. The first real significant difference was the question of reparations. This issue was the most sensitive and responsible for many bitter arguments among winners and losers, but also among the victorious countries. The new smaller countries of Central and Eastern Europe had Hungary and Austria as their main targets in this aspect. Finally, in the case of Austria, the reparation payment 
was put off for twenty years.965 It meant that during the whole term of the loan, Austria was freed from a heavy financial obligation. The reason for this was political. Austria was in really dire straits, so much so, that, with Great Britain in the lead, the contemporary European community accepted that if Austria was to be saved, some sign of magnanimity was essential. Great Britain did not want to see Austria collapse because it feared such a scenario might spread to the whole region, which ran against British aims in Central Europe. With their prestige and influence in and out of the League of Nations, the British in the end successfully exempted Austria from reparations during the service of the loan.

As for Hungary, the picture was different in two ways. First, Hungary's overall situation in 1923 looked much better than that of Austria in the previous years. Being an agricultural country, Hungary was at least able to feed itself, so the rampant famine experienced in Vienna was not a real threat. On the other hand, one of their main political aims of the Little Entente was to squeeze out of Hungary as large reparations as possible. Since the peace treaty did not specify the amount to be paid, Hungary's hostile neighbors were not content to sit and watch idly as Hungary was getting international money without paying reparations to Czechoslovakia, Romania, Yugoslavia, or Italy. It took many rounds of bitter and fierce negotiations and often British blackmailing to achieve a compromise. Hungary did get the international loan but it had to pay reparations. The amount was an average of 10 million gold crowns (\$2 million) a year for twenty years, which meant 1.25 gold crowns $(\$ 0.25)$ burden per annum per capita of the population, with the alleviation that payments had to start in earnest only from 1927, when the reconstruction program had supposedly ended, and the yearly sum showed a progressive scale starting with smaller amounts climbing toward bigger ones. ${ }^{966}$ The idea was that with the help of the reconstruction program, Hungary would be in a position to be able to pay.

Another important difference was the amount of money the international loans provided for the two countries. This question also touched upon the assumption that Austria was in next to impossible conditions whereas Hungary was able to provide food for its own population. In line with this thought, Austria was received the net amount of 613 million gold crowns, roughly the equivalent of $\$ 125$ million. True, out of this money, Austria had to pay back earlier financial commitment to Great Britain, France, Czechoslovakia, and Italy to the extent of 130 million gold crowns, which sum represented $25 \%$ of the loan. ${ }^{967}$ Britain had given so much money prior to the League of Nations loan that it was essential

965 In the end, there was no reparations paid by Austria and after World War II the situation was the same, although for somewhat different reasons.

966 Royall Tyler, "The Eastern Reparations Settlement," Foreign Affairs 9 (October 1930):

111; League of Nations, The Financial Reconstruction of Hungary, 201-02.

967 League of Nations, Financial Reconstruction of Austria, 143-46. 
to be reimbursed to some degree, while in the case of Czechoslovakia, it was a political deal that it should receive some of its money back in exchange for the Loan Protocols. It was decided that Hungary was to be given a much smaller amount despite the Hungarian government's efforts for a similar sum. In the end, Hungary received a net 253 million gold crowns, approximately $\$ 50$ million, which was $40 \%$ of what Austria had been given. Although the terms of issue were not favorable for either country, Hungary came off better. While the Austrian rate of issue was $83 \%$, the Hungarian was $88.5 \%$; the rate of interest was $6.3 \%$ in Austria's case and $7.5 \%$ for Hungary, the figures representing the average. With hindsight, it can be easily concluded that the men behind the plan had sized up the conditions and possibilities well and both countries got the adequate amount. A further difference was how the two countries were allowed to redeem the loan. A major alteration was that in the case of Hungary any amount of money saved in terms of principal and interest, typically through purchase in the market, could be used for amortization, whereas in Austria's case it was only the principal that counted. The idea was that with this method the redemption of the loan was going to be quicker, a point on which the bankers insisted. ${ }^{968}$

Another reason why Austria was provided with a larger sum was the guarantee certain powers undertook on its behalf. The state of Austria was so devastated and the political circumstances showed a possibility of serious turmoil that the possibility of raising a loan was only possible with certain guarantees. In the end, the principal countries took responsibility for a long-term loan, which was guaranteed as follows: Great Britain, France, and Czechoslovakia 24.5\% each, Italy 20.5\%, Belgium and Sweden $2 \%$ each, Denmark and the Netherlands $1 \%$ each. In the case of Hungary, on account of the better financial conditions, and the successful execution of the Austrian long-term loan, the League of Nations was of the opinion that no state guarantees would be necessary, especially for a much smaller amount. The negotiations for the Hungarian loan showed that this was a somewhat optimistic view and the issue of the loan was far from easy. It cannot be, however, said that with state guarantees it would have been any easier.

Also, in many ways as a consequence of the previously listed differences, the Protocols showed several minor discrepancies. Although in their main lines they were very similar, the differences shed light on the divergent nature of the two reconstructions. In both cases, the first one was the so-called Political Protocol. These were almost identical, but Austria had to promise not to alienate its independence (a further insurance against the Anschluss). Hungary, on the other hand, had to pledge that it would carry out the obligations stipulated in the Treaty of Trianon, especially the military clauses. The Austrian case was in

968 Leese to Smith, June 21, 1924, OV33/76, BoE. 
deference to Czechoslovakia and Italy, while the requirement for Hungary was obviously spelled out according to the wish of the successor states. As far as the Committee of Control was concerned, there were variations. In the case of Austria, the duties and powers of this body were detailed in a separate Protocol, whereas in the Hungarian Protocols this part was only an article of Protocol No. $2 .{ }^{969}$ Naturally, in the first such undertaking, the emphasis was very large on control, and that is the reason why the League found it necessary to have it drawn up in a separate Protocol. By the time the Hungarian Protocols had to be completed, it was apparent that the control the Commissioner-General could exert was enough for the aims, and in the case of Hungary this feature was not emphasized as strongly. In the Hungarian Protocols, some of the powers of the Committee were also given over to the Commission-General. Moreover, in the Austrian Protocols no mention was made about Trustees and only in late 1925 did the Council set up a system of trustees, similarly to the case in Hungary, to control the assigned revenues. ${ }^{970}$ Aside from these points, the two sets of Protocols and the means of control they set out were essentially identical, which was a further proof that the League of Nations wished to set up a workable system for financial reconstructions, because it knew that it had to deal with other countries on the continent.

In the field of control, the embodiment of extra control was the Bank Adviser in both cases. It was seen as essential that the new central banks, both independent of the governments, should be watched over exactly to help them retain that status and to forestall murky deals that would have endangered their independence in any way. The major difference, naturally, was at the end of both reconstructions. In the case of Austria, the League of Nations made the requirement that the Adviser should remain in office for three more years after Zimmerman's office was terminated. In Hungary no such extra safety regulation was needed. Article 127 of the Statutes of the Hungarian National Bank read as follows, "The functions of the Adviser shall terminate at the same date as those of the Commissioner-General of the League of Nations [...] A Bank Adviser will be re-appointed either when the control by a Commissioner-General is re-established (Article VII of Protocol II) or when Treaty charge transfers are discontinued for two years or more (Article XIII, para. 3)."971 Arthur Siepmann's term as Adviser to the National Bank ended on the same day as that of Jeremiah Smith, Jr., June 30, 1926, and they left Budapest together.

969 League of Nations, Financial Reconstruction of Austria, 139-42.

970 Note to the members of the Financial Committee, May 9, 1926, Financial Reconstruction of Hungary, Memorandum on the technical and legal conditions for the eventual suspension of the control of the Commissioner-General in Hungary. Doc. No. 51442, Registry Files, R. 301, LNA.

$971 \mathrm{lbid}$. 
An interesting divergence was the currency on which the Austrian and Hungarian crowns were stabilized. In the case of Austria, it was the US dollar that the Austrian crown was based on, a feature that did not meet Norman's expectations and support. In all likelihood, as the Austrian reconstruction was a first step and no one was sure about the rest, Norman did not push for a sterling-based Austrian currency, partially in deference to his American counterpart, Benjamin Strong. However, when the Hungarian loan was managed and about two-thirds of it was coming from London, Norman was adamant that the Hungarian currency should be pegged to the British pound sterling. ${ }^{972}$ For Norman it was not only a question of prestige; this policy fell in line with his idea of European reconstruction, where London would be the leading player and the center of things. ${ }^{973}$

In both countries, a lot of attention was given to the conditions and numbers of state officials. This was a point on which reforms were absolutely necessary. In both countries a swollen staff of state officials worked, which prevented a welloiled state machinery. Moreover, their salary ate up much of the expenditure of the budget. In Hungary, for example, Smith and others kept complaining that the salary of state officials was $60 \%$ of the yearly budget. Austria was to dismiss 100,000 officials during the reconstruction period out of 250,000. The League considered even this number inefficient, but social disturbance and outrage were two factors that they wanted to avoid. As was mentioned earlier, Austria never fully lived up to this expectation. In Hungary's case, the number of officials was significantly smaller, but it was proportionally still too large. A reason for this was that many state officials arrived from the ex-territories and the Bethlen government thought it only fair to let them retain their jobs. This gesture may have been politically right and from a human point of view admirable, but it put extra strain on a weak Hungarian economy, currency, and budget. As the Bank Adviser accurately prophesized it in the beginning of the reconstruction period, "the Beamtenfrage will be with us until the end of time." 974 Hungary played with the ratio of multiplier and, at the end of the day, the 15,000 state officials that Hungary was required to dismiss during the two and a half years of reconstruction was a much easier target to reach than in Austria. Despite the fact that the question was a sensitive one, since these officials earned very little money and they faced prolonged unemployed status once on the street, Hungary was actually able to top this number somewhat.975

972 Péteri, Global Monetary Regime, 92.

973 Lojkó, Meddling in Middle Europe, 11-12.

974 Siepmann to Strakosch, July 27, 1924, 1/1924. May-June, K 304, Siepmann Papers, HNA.

975 2/VIII/8, K 288, Papers of the Financial Delegation to Geneva, HNA. 
The League put the emphasis on limiting expenditure in the case of Austria. This was thought to be the main cause of the financial woes, and the idea was that if Austrians learned how to economize, long-lasting results in the financial and economic domain might be achieved. In the case of Hungary, the League emphasized taxation. The League thought in Hungary there was "an inertia in trying to raise money and an unwillingness on the part of the people to contribute to the expenses of government.."976 Whereas Viennese in particular were willing to accept high taxation, the population in Hungary, especially in the country, was not. The measure of the taxes of the Hungarian population was a constant question during the time of reconstruction. The League estimate proved wrong in the case of Austria in the sense that the country never mastered saving on state level and the expenditure kept rising. Balanced budget was achieved through increased taxation rather than economies.

Last, but not least, it must be noted how the two countries fared after the reconstruction programs were concluded. In many ways, the real test of the League of Nations reconstruction programs came after they were concluded. As long as a League controller was in place, it was relatively easy to ensure that both countries would follow the guidance coming from Geneva. The real question was how they were going to act once their financial freedom was achieved again. Would they adhere to the introduced reforms and strict fiscal policies, or would they fritter away what they had gained in the previous period?

One of the initial intentions of the League of Nations programs, namely that once the financial conditions were put right, the foreign capital would start flowing in and the economy would become thriving, partially came true. In both countries, now declared financially stable, foreign investors saw a good market for their money. For a few years to come, both Austria and Hungary became relatively safe investments, and they became part of the loan boom so typical of the years between 1924 and1928. Both countries had some surplus remaining from the international loans. Austria, with the agreement with foreign creditors, spent most of the money on improving the railways and the telegraph system. ${ }^{977}$ Hungary spent its remaining loan money on projects not strictly connected to reconstruction. Unfortunately, this trend was a characteristic of all loans coming to Hungary. Only $20 \%$ of the long-term loans in the 1920 s were used for productive investments; $25 \%$ of it was used to expand the state bureaucracy, luxury building constructions, all in all, for consumption goals.978 Still, the financial year ending on June 30,1927, produced a large surplus, savings and

976 Alzada Comstock, "The Technique of Reconstruction as Applied to Hungary," Political Science Quarterly 40 (June 1925): 209.

977 Berger, "Rebuilding Economies after External Shocks," 70.

978 Berend and Szuhay, A tökés gazdaság, 220. 
the gold stock of the National Bank rose further, while the State debt to the Bank, the number of insolvencies and the unemployed declined significantly. As a real sign of short-time success, average real wages had doubled since the reconstruction program started in $1924 .{ }^{979}$

At this stage overborrowing seemed a remote possibility, although the first signs were there. Still, if someone saw it, in the end no mention was made of it, because everybody was interested in the successful conclusion of the work. But this characteristic proved very grave for both countries in the end. Short and long-term loans arrived in such big numbers that after a while the debt grew so large that newer loans were needed to pay off the old ones. On behalf of Hungary, for example, in the three years following the reconstruction 38 longterm loans were issued. ${ }^{980}$ It is little wonder that the country was heavily indebted by the end of the decade. Still, in the second half of the twenties, both countries could boast of a balanced budget and a gold-based currency. By 1930, however, a sudden change had occurred. Both had a state budget with serious deficits and the central banks had lost most of their foreign currency reserves. ${ }^{981}$ The main problem again was the inappropriate usage of loan moneys. As the British Royal Institute correctly summed up in the early 1930s, "Foreign loans that were used for the reconstruction of Europe were needed, but in the end, the sum was bigger, than the debtors could have hoped to be able to pay back." ${ }^{\prime 92}$ One of the reasons leading to this sorry state of affairs was that on the European continent "a significant portion of the invested loans was mainly used for unproductive goals, which raised the level of standard of living in the given country, but did not create such improvement in the efficiency of these countries' exports that they could be able to fulfill their debt obligations." ${ }^{\text {983 }}$ With such mindset and short-term planning, it is no wonder that the League reforms were not able to create long-term prosperity.

The other fatal blow to both countries was the Great Depression out of which neither country really found a way. This crisis, which maimed economies and financial institutions all over the world, left neither county intact. Still, until the Credit-Anstalt crisis in Austria in 1931, in which the biggest bank of the region collapsed, both countries faithfully kept paying their loan annuities. Both countries asked for help from the League of Nations again, but despite some

979 Eugene Havas, Hungary's Finance and Trade, 1927 (London: General Press, 1928), 7, 25-27, 35-36.

980 lbid., 218.

981 Ágnes Pogány, Párhuzamos történetek [Parallel Stories]. In. Ötven éves a Budapesti Közgazdaságtudományi Egyetem [Budapest University of Economic Sciences Is 50 Years Old]. vol. 2 (Budapest, 1998): 1214-28.

982 Quoted in Berend and Szuhay, A tökés gazdaság, 221.

$983 \mathrm{lbid}$. 
short-term credits and insignificant help, the problem could not be solved. All through the next few years, both Austria and Hungary were in shaky but manageable conditions. Default on foreign bonds became the norm rather than the exception. Though Hungary always paid its dues after the League of Nations loan, when it came to other loans, and American ones were a major part of them, the situation proved different. The Hungarian government put the United States Government Relief Loan second on its priority list, yet it did not undertake to meet the roughly $\$ 7,000,000$ per annum annual service charge on other dollar bond issues. ${ }^{984}$ Strange as it may seem, the only real way to reach some prosperity for these countries again was the coming of World War II, for which, though, both had to pay a dear price.

\subsection{Other Schemes in Europe by the League}

After the Austrian reconstruction had been launched and the first signs of success were manifest, the League of Nations wanted to spread its services in this field to further countries in great need of outside help to reach financial stabilization. It is worth taking a quick view of the other rehabilitation efforts in a chronological order. In two cases, namely in Greece and Bulgaria, the League stepped in twice years apart.

The situation in Greece was different than in Central Europe. The country was experiencing a huge wave of refugees. These were of Greek nationalities fleeing from Turkey and their number reached more than a million, which represented about $25 \%$ of the whole population. For some time, the American Red Cross had carried out relief work in Greece. Until June 30, 1923, it had spent \$3 million, but wanted to get out because the problem seemed to be a permanent one requiring huge sums of money. ${ }^{985}$ Greece turned to the League of Nations for help. Parallel, Norman gave $£ 1$ million advance to the Bank of Greece with the condition that the chair of the pending committee would be an American.986 Indeed, the Refugee Settlement Commission was established and Henry Morgenthau of the United States became its Chairman, who was later succeeded by another American, Charles P. Howland.987 The Protocols were signed in September 1923,

984 Allen W. Dulles, "The Protection of American Foreign Bondholders," Foreign Affairs 10 (April, 1932): 481.

985 Correspondence between Payne (Chairman of the American Red Cross) and Phillips (Under Secretary of State), February 19, February 28, and March 1, FRUS: 1923, 2:318-22. 986 The Chargé in France (Whitehouse) to the Secretary of State, August 25, 1923, Ibid., 371-72.

987 Marx Winkler, The Investor and the League Loans (New York: Foreign Policy Association, Volume 4, June 1928, Supplement No.2), 20. 
and in November 1924, a loan of $\$ 60$ million was issued, of which $\$ 11$ million was offered in New York, $£ 7,500,000$ ( $\$ 33$ million) in London, and $£ 2,500,000$ ( $\$ 11$ million) in Athens. ${ }^{988}$ The rate of interest was $7 \%$ and the issue price was $88 .{ }^{989}$ Greece had to make every effort to balance its budget, and the Council had the right to supervise the Refugee Settlement Commission's work and to give decisions pertaining to that work. ${ }^{990}$ The majority of the refugees were successfully settled by the end of the work.

The pledge on Greece's side to carry out a fiscal policy that would ensure a balanced budget remained merely rhetorical. Not surprisingly, soon enough Greece asked for the League's help again in securing another loan. In a new Protocol signed, Greece undertook to stabilize its currency, set up a new Bank of Issue, maintain a balanced budget, and pay off arrears of debt. Of the $£ 9$ million (\$39.6 million), one third was spent to increase the liquid assets of the Bank, one third to pay off arrears of debt, and one third to continue the refugee settlement work. The second Greek loan was issued early in 1928. The amount was \$36 million, of which $\$ 17$ million was offered in the United States and $£ 4,070,960$ ( $\$ 19.8$ million) in London. The rate of interest was $6 \%$ and the price of issue was 91. The United States took so large a part, because according to an agreement with Greece, out of this loan Greece would be enabled to pay back war indebtedness to the US. There was no guarantee for the loan by other governments and no Commissioner-General was appointed. But as usual, a Bank Adviser was appointed for three years. It was a British citizen, H. C. F. Finlayson, whose office was twice renewed, all the way until 1934. In 1929, a further $\$ 12,000,000$ was raised in the USA exclusively for refugee settlement work. Though Greece this time performed well, the Great Depression made those results soon disappear. In 1932 Greece unilaterally suspended the transfers for its foreign debt service and all through the 1930 s it was unable to meet its payment commitments. ${ }^{991}$

Danzig was an extreme case of the various peace treaties. It became a socalled "free city," which was due to its unique position as the most important port city in the region. The League of Nations already in 1921 dealt with the question of Danzig, when the High Commissioner there proposed that the League should guarantee a loan. Nothing came of it. Then in January 1923, the Reparations Commission granted a one-year moratorium for Danzig on payments. In September 1923, the Danzig Senate decided to introduce a new

\footnotetext{
988 Ibid., 21.

989 League of Nations, Reconstruction Schemes, 60.

990 lbid., 59.

991 The paragraph is based upon League of Nations, Reconstruction Schemes, 61, 68, and, 73; Winkler, 21. The issue of the American tranche was dependent upon Greece concluding the debt settlement with the United States, which finally, although a little bit later, took place. FRUS: 1927, 3:1-19, and FRUS: 1928, 3:1-13.
} 
currency and set up a new bank of issue early next year with the financial help of the Bank of England, thus the new currency was based on sterling. The first loan was a municipal one issued successfully in London in the spring of 1925. Its interest rate was $7 \%$ and it was mainly used for development works. Then Danzig got in financial trouble and the League proposed in September 1926 that a long-term loan should be issued for balancing the budget and for certain productive purposes. Since requirements were slowly executed by the city, the loan was issued only in June 1927 . The interest rate was $6.5 \%$; the amount was $£ 1.9$ million (\$9.2 million), of which the biggest part was used to pay off treaty charges. Danzig faithfully executed its annuities and stopped paying any further transfer only two months before it was incorporated into Germany. ${ }^{992}$

Bulgaria's case was different from other ex-enemy countries in the sense that it was the only country whose reparation obligation was spelled out in the Treaty of Neuilly in late 1919, to the amount exceeding $\$ 400$ million. After Bulgaria asked for a three-year moratorium on this obligation, negotiations began, and in February 1923 the reparation was reduced to $\$ 100$ million with favorable terms of payment. ${ }^{993}$ The successful Austrian and Hungarian reconstructions persuaded Bulgaria to turn to the League of Nations for help. Though in 1925 the British Treasury opposed a League loan for Bulgaria because they thought it would rob the League of some of its prestige, in 1926 both the Treasury and the Bank of England approved of such a course, in which the positive behavior of Bulgaria in the conflict with Greece in the fall of 1925 might have played some role. ${ }^{994}$ The high number of refugees further made Bulgaria's situation more difficult. There number was much lower than in Greece, still, it put a heavy burden on the government, which found itself in financial turmoil.

The League of Nations drew up a plan for Bulgaria and a protocol was signed in September 1926.995 René Charron was appointed Commissioner, who had to submit quarterly reports. For the settlement of refugees, a loan of $£ 2,250,000$ ( $\$ 11$ million) was to be raised. Just like in Austria and Hungary, the loan was to be secured by specific revenues and was to have a first charge on any other revenues in case of need. In December, a long-term loan was issued in London (\$8.3 million), in Italy, Switzerland, and the Netherlands (\$3.2 million), and New York $(\$ 4,500,000)$. The price of issue was 92 and the rate of interest was $7 \%$. Of the nominal amount of $£ 3.3$ million ( $\$ 16$ million), $£ 625,889$ ( $\$ 3$ million) was used to settle claims by France originating from before World War I. Another Protocol

992 The paragraph is based upon League of Nations, Reconstruction Schemes, 98-105, and Orde, British Policy and European Reconstruction, 279.

993 Orde, British Policy and European Reconstruction, 289.

994 Ibid., 289-90.

995 All the information in this paragraph is from League of Nations, Reconstruction Schemes, 80-97. 
in March 1928 spelled out a scheme for a financial reconstruction with the help of a foreign loan of $£ 4.5$ million ( $\$ 22$ million) secured on customs revenue, later increased to $£ 5$ million because of the earthquakes. It was issued in November and December 1928, in London ( $\$ 8.8$ million), New York ( $\$ 13$ million), and Paris ( $\$ 2.4$ million). The prices of issue were 96,97 , and 93 , respectively; the rate of interest was $7 \frac{1}{2} \%$. The number of state employees was to be reduced by at least 10,000 in two years. The Bank Statutes were very similar to those of Austria and Hungary, but a little bit stricter. In September 1928, Charron was also appointed Technical Adviser to the National Bank, and he held both positions until 1932. The work was practically finished in the fall of 1931. In 1932, Bulgaria first decided to partially and temporarily suspend transfer payments, which meant a $50 \%$ reduction, then in 1934 , it unilaterally started to pay only $15 \%$ of the interest. Finally, in 1940, Bulgaria defaulted on its League loan.

Estonia, the new independent small state, arrested inflation and reached budget equilibrium on its own. In 1926, however, it turned to the League of Nations for advice. The League suggested the Estonians should set up a new bank of issue along modern lines. The Estonians accepted the recommendation and a protocol was signed on December 10, 1926. A financial adviser was appointed to the government. Walter J. F. Williamson became the adviser to the new bank from May 7, 1927, and remained in that position till September 1930. The long-term loan to be issued was to be spent mainly on the new bank and on a new mortgage institute. In June the British issue was $£ 700,000$ ( $\$ 3.4$ million), the American $\$ 4,000,000$, the price of issue was the same in both countries, 94.5; the interest rate was 7\%. Currency and banking reforms were carried out according to the protocol and Estonia was a real success story. Even the Great Depression caused a relatively small disturbance in the state's financial affairs. Up until Estonia was incorporated into the Soviet Union, the country maintained the full service of the loan.996

The abovementioned programs, together with the Austrian and Hungarian ones, can be said to have been successful as far as their original goal was concerned. ${ }^{997}$ A new central bank was set up in each country, inflation was arrested, the budget was stabilized, and with the help of an outside loan, the financial means were at hand to accomplish far-reaching reforms. In wake of the early signs of stability, foreign capital started to come to these countries, which in the end led to overborrowing. It is very interesting that out of all these countries, the per capita foreign debt service was the highest in the two real success stories, Austria and

996 This paragraph is based on League of Nations, Reconstruction Schemes, 106-09.

997 There were plans and negotiations for a League loan for Albania and Portugal in 1924 and 1927-1928, respectively, but both came to naught in the end. In more detail about the two cases, see, League of Nations, Reconstruction Schemes, 110-24. 
Hungary. ${ }^{998}$ As Smith was said to have remarked frequently, "This scheme is doing altogether too well. I don't know what's going to happen. But something is sure to go wrong, somewhere." successful from a financial point of view, economic soundness and large-scale cooperation among the other countries broke down. As a consequence, the mechanism that was to ensure a revitalized Europe in economic terms was not operating. This was destined to lead to trouble and in only a few years' time the region, together with the whole world, found itself in the deepest economic and financial crisis modern society had ever faced.

\subsection{Reconstruction Programs outside the League}

The problems mentioned in the above chapters were not unique to the Central, Eastern, and Southern European regions. In almost every country in Europe some kind of financial rehabilitation was necessary in order to create the basis of a new Europe in the financial and economic spheres in the 1920s. Some other countries that also needed to step on the path of financial recovery with outside help, however, chose a different course than that of the League of Nations. A short overview of these examples is all the more well-founded, because all these countries represented a different political problem. With the conspicuous exception of Germany and Poland, the countries that undertook financial overhaul did not carry the threat of political instability and the fear of spreading Bolshevik ideas. The chapter first deals with these countries, then turns to Germany and Poland.

The talks had been going on for the stabilization of the Belgian franc for more than a year before the final agreement was made in October 1926. The negotiations were basically handled by Norman and Strong, therefore, it was a genuine Anglo-Saxon undertaking. The currency was to be stabilized at a gold value, the Belgian government was to secure a long-term foreign loan of roughly $\$ 100$ million, and the Belgian National Bank had to arrange for about \$41 million credit form other central banks. Norman called this central bank cooperation "a miracle," especially because the central banks of both Germany and France took part, a unique cooperation between archenemies. As a sign of real central bank effort, even small countries such as Austria and Hungary participated with $£ 500,000$ ( $\$ 2.4$ million) each in the central bank credit. Since the major part

998 Ibid., 150.

999 Quoted in Ibid., 152. 
of the loan was supposed to come from America, it was well within Belgium's interest to reach a debt settlement with the United States. This was duly done and according to plans, $\$ 50$ million out of the total $\$ 100$ million was issued in the US. The price of issue was 94, a high figure in European loans during the 1920s; the interest rate was 7\%. No specific revenues were assigned as security for the loan. The Belgian case provided the first case when the League assistance was avoided and rather central bank cooperation was put in practice. A lot of elements were taken over from earlier League loan cases as might be expected. However, there was the conspicuous lack of foreign controller like Smith in Hungary, and no real control was set up. The closest manifestation of control was the Bank of England's request for periodic reports from the National Bank of Belgium about the progress, which it received. ${ }^{1000}$

Italy also wanted to get a share of the loan boom engulfing Europe and it needed some outside help. The debt settlement concluded with the United States in November 1925 helped Italy's case and, accordingly, J. P. Morgan \& Co. floated the $\$ 100$ million Italian stabilization loan within weeks. But the lira soon started to fall and other measures were needed in order to secure a stable currency. One of the main reasons was the lack of an independent central bank in Italy, where the Mussolini regime held sway over it. In December 1927, the Norman-Strong pair started the negotiations in earnest after some preparation work, and a week later an agreement was hammered out. The $\$ 75$ million central bank credit by 15 central banks was carried out with the lead of London and New York, the two latter also securing $\$ 50$ million private credit, but Austria and Hungary also participated with a smaller sum. The independence of the National Bank of Italy was not really restored, but the participants did not deem it as the most important aspect and no control similar to any of the League loans was set up. In 1929 the again stable lira started to lose its value and in the 1930s Italy stepped on the road leading to military expansion and fiscal policy was subordinated to such a course of action. ${ }^{1001}$

Romania was another country where the help of the League of Nations was avoided despite Norman's effort to secure it. Similarly to Poland, the Romanians did not want any League control and they were lucky to find an influential friend. France, who by this time had become financially strong, believed that Romania could be a place to oppose Norman's scheme for League action. In 1929, Charles Rist was appointed Technical Adviser to the National Bank, succeeded by another French man, Roger Auboin. In December a Protocol was signed. The

1000 This paragraph is based on Meyer, Bankers' Diplomacy, 16-41, and Chandler, Benjamin Strong, 351-53.

1001 The paragraph is based on Meyer, Bankers' Diplomacy, 42-57, and Chandler, Benjamin Strong, 388-89. 
National Bank of Romania got a $\$ 25$ million credit from 14 central banks, with the United States, Great Britain, and France each taking $\$ 4.5$ million, while smaller countries such as Austria and Hungary had a share of $\$ 500,000$. Romania also secured a $\$ 101$ million long-term foreign loan, with the largest offering of $\$ 22$ million coming from France. As a compromise, the Financial Adviser was to be in Romania only for 4 years instead of 5, but agreement between as to who that person should be never took place. The two British persons offered were not accepted by Romania. Rist, the Adviser, had even less power than in the Polish case. He did not have "authority even to control the use of the loan proceeds or the revenues pledged as security for the loan." He was there for three years as a figurehead and he stayed in Bucharest only in the first year of the program. Although Romania stabilized her currency, the world crisis hit her hard and the country asked for League help in 1932. The League drew up a scheme but in May 1934, Romania officially renounced the agreement and the financial plan was never used. ${ }^{1002}$

Germany was a much different case than all the other countries mentioned so far. This was the pivotal question in Europe: what to do with Germany? The Versailles Peace Treaty in 1919 said that Germany was responsible for World War I and was to pay interim reparation of 20 billion gold marks ( $\$ 5$ billion) before May 1, 1921, to other countries, and the Reparations Commission was supposed to fix the total sum by that date. Indeed, on April 27, 1921, the Commission announced the total money to be paid by Germany was 132 billion gold marks (\$33 billion). ${ }^{1003}$ The London Schedule of Payments of May 5, 1921, basically created a myth about this sum. On the one hand, the 132 billion was maintained as a set figure toward the public, but in reality the true amount was cut down to 50 billion gold marks ( $\$ 12.5$ billion). ${ }^{1004}$ The Allies were well aware that Germany could not pay the originally set amount, but politically it was impossible for them to retreat. Soon enough Germany stopped paying the yearly installment due to weakened economic conditions. In large part this was due to the German plans to let the financial situation get worse in the hope that the reparation measures would be reduced with time, a tactic that paid off in the end. ${ }^{1005}$ As a response to the lack of living up to the agreement on the German part, French and Belgian troops occupied the Ruhr Valley in January 1923, which was considered the most valuable asset of Germany. The United States felt it had to do something in order to create an escape route out of this chaos.

1002 This paragraph is based on Meyer, Bankers' Diplomacy, 101-35, Chandler, Benjamin Strong, 404-05, 422, and League of Nations, Reconstruction Schemes, 125-32.

1003 For text of the Reparation Commission decision, see FRUS, PPC, 13:433.

1004 Sally Marks, "The Myths of Reparations," Central European History 11 (September 1978): 233-37.

1005 lbid., 239. 
The United States had an enormous stake in Germany and it was in its best interest to arrive at an agreement with the other parties. Germany was seen as the center for both the political and economic problems. As Norman Davies warned Woodrow Wilson, "If Germany is not at work," it would be "in a chaotic condition and unprosperous," therefore it would be "impossible for the rest of Europe to get to work and be prosperous." ${ }^{1006}$ Thomas Lamont later recalled that "the British and ourselves regarded Germany as the economic hub of the European universe. We feared that unless Germany were rebuilt and prospered all the surrounding countries of the Continent would likewise languish." ${ }^{1007}$ Political and ideological points of view also played a role. The United States did not want to see a broken and very weak Germany in the heart of Europe, because that would have meant French hegemony on the continent and a possible German tendency toward Bolshevik sentiment. It meant responsibility, which America's first postwar ambassador to Germany, Alanson B. Houghton, well recognized, shared, and hoped to implement in practical actions. As he put it,

The American people must understand their responsibility and their opportunity. God has given us the power to render a vast service to humanity. No such opportunity has ever come to any nation in two thousand years. The world has become an economic unit. The United States must recognize this and shape her policies in accord with this new fact in her history. The idea of isolationism must be dismissed. The sentiment and the sense of responsibility for building a better world civilization must be cultivated. ${ }^{1008}$

The largest debtors to the United States, Great Britain and France, paid their dues out of the reparation installments they managed to squeeze out of Germany. If Germany could not pay, the United States would not have received money from the Allies either. Therefore it was vital for America to find a solution for the intricate problem.

Although the US government systematically denied any relation between war debts and reparations, the highest political voices made it clear what the United States wished to see. Secretary of State Charles Hughes already in 1922 hinted that the United States would be interested in reaching a consensus as far as Germany was concerned:

1006 Quoted in Costigliola, Awkward Dominion, 37.

1007 Quoted in Chernow, The House of Morgan, 248. The British shared this view. As the foreign minister, Lord Curzon announced to the cabinet, Germany "is to us the most important country in Europe." Quoted in Ahamed, Lords of Finance, 116.

1008 Quoted in Jeffrey J. Matthews, Alanson B. Houghton. Ambassador of the New Era (Lanham, MD: Rowman and Littlefield, 2004), 47. Houghton was fluent in German and can be said to have had a Germanophile attitude. 
If statesmen cannot agree, and exigencies of public opinion make their course difficult, then there should be called to their aid those who can point the way to a solution. Why should they not invite men of the highest authority in finance in their respective countries-men of such prestige, experience and honor that their agreement upon the amount to be paid, and upon a financial plan for working out the payments, would be accepted throughout the world as the most authoritative expression obtainable? [...] I have no doubt that distinguished Americans would be willing to serve in such a commission. ${ }^{1009}$

Naturally, one of the reasons why the United States was willing to take a decisive role in the negotiations was the basic difference that unlike the previous Central European countries' loans, the German reconstruction would not be under the auspices of the League of Nations. In the cases of Austria and Hungary, American private capital took only a lukewarm albeit very important part. In the case of Germany, so much more money was needed that it seemed impossible to solve the financial question without Americans right from the very beginning. Therefore it was insured that whatever method would be agreed on, it needed to have American blessing. This was only possible outside the framework of the League of Nations. Not surprisingly, despite the large role the United States was sure to play in the German question, at least on the economic front, the administration did not assume any larger political liability than before.

The formative period of what came to be known as the Dawes Plan was a good occasion for American officials to express once again that they took no responsibility for any loans issued on the American market. President Coolidge was quick to declare that no American would go as a representative of the US government and the government did not participate officially in the German reconstruction. ${ }^{1010}$ Economic Adviser of the Department of State Arthur N. Young's address repeated the same line of thought. ${ }^{1011}$ But American experts playing a crucial part in the plan to resolve the German reparation question clearly added an American flavor to the whole settlement. The official White House statement said that "It is the desire of the Administration that the Dawes Plan should be put into effect as speedily as possible. This is the first and essential step to economic recovery abroad in which this country is vitally

1009 Hughes at the Annual Meeting of the American Historical Association at New haven, Connecticut, December 29, 1922. Hughes, The Pathway of Peace, 57.

1010 Quint and Ferrel, eds., The Talkative President, 178, 180.

1011 Text of address of Dr. Arthur N. Young, August 26, 1924. "The Department of State and Foreign Loans." No. 14. 21, S. 118, Salter Papers, LNA. 
interested." 1012 It is clear that the main interest of the United States in Europe related to Germany. The rest of Europe was judged in relation to this country. To the east, it was essential to have stable governments, so the Bolshevik ideology could not spread to and fester the new states; to the west, the task was to ensure that Germany would be e able to climb back to the community of strong and prosperous states.

With American initiative then, an expert committee started serious work on how to fix the problem. The fruit of their labor was the so-called Dawes Plan, the name coming from the chairman of the committee, Charles Gates Dawes. ${ }^{1013}$ There was another committee investigating German holdings abroad. The plan, in many ways, built upon the Austrian and Hungarian reconstruction programs, and thus can be seen as a continuation of the work started there. Moreover, from a political point of view, the two earlier Central European financial reconstructions must be seen as the prelude to this effort. However, in Germany, the stakes for many countries were much bigger than in tiny Austria and Hungary.

Dawes announced the committee's recommendations on April 9, 1924. The main points were as follows: the Ruhr Valley must be evacuated ${ }^{1014}$; the German central bank (Reichsbank) was to be reorganized; a loan of $\$ 200$ million was to be issued, of which the largest part, $\$ 110$ million, would be subscribed in the United States; currency stabilization and a new monetary unit, the Reichsmark, was introduced; no set figure for reparation was established, but rather a scale of payments based on financial prospects in Germany was set up, starting with two hundred and fifty million dollars ( 1 billion gold marks), and reaching six hundred and twenty-five million dollars ( 2.5 billion gold marks) four years later; it was insured that payments did not threaten the financial stability of Germany; largely to enforce this point, the appointment of an Agent General for Reparations Payments was a prerequisite. ${ }^{1015}$

The clear manifestation that the US government was committed to the success of the plan came from the highest authorities. President Coolidge spoke up for the German reconstruction with heavy American involvement:

1012 Hughes to Kellogg, June 25, 1924, FRUS: 1924, 2:32.

1013 Out of the ten members, Dawes and Owen Young represented the United States.

1014 French and Belgian troops occupied the region on January 1, 1923, on account of Germany defaulting on reparation payments. In accordance with the later agreement, the Ruhr Valley was evacuated by the foreign troops on August 31, 1924, prior to the start of the Dawes Plan.

1015 In more detail, see Harold G. Moulton, The Reparation Plan (New York: McGraw-Hill Book Company, 1924). 
I trust that private American capital will be willing to participate in advancing this loan. [...] We have determined to maintain, and can maintain, our own political independence, but our economic independence will be strengthened and increased when the economic stability of Europe is restored. [...] A final adjustment for the liquidation of reparations ought to be the beginning of a new era of peace and good will. ${ }^{1016}$

Secretary of State Hughes also gave a good hint of how the US government assessed the Dawes Plan and American involvement in it:

You may count upon our interest and assistance in the necessary measures to assure the economic rehabilitation of Europe. It does not matter that this aid is not given by the government. Without wishing to say anything controversial on this occasion, I may give it as my conviction that had we attempted to make America's contribution to the recent plan of adjustment a governmental matter, we should have been involved in a hopeless debate, and there would have been no adequate action. We should have been beset with demands, objections, instructions. That is not the way to make an American contribution to economic revival. You have the Dawes plan and you have had the participation of American experts, with the liberty of constructive effort which was essential because it was undertaken in the only way in which success was possible. When you deal with economic rehabilitation, you doubtless have in mind such contribution as America may be able to give in disinterested advice, and later, in participation in the absolutely essential loan. [...] We appreciate the difficulties, but we believe that the Dawes plan opens up the path of confidence and prosperity. For that reason, we are deeply interested in its prompt execution. ${ }^{1017}$

Once more, the official expressions were trying to blur the lines between clear governmental commitment and pure business undertaking, the relation between reparation payments and intergovernmental debts, and between the depoliticized outside cover and the deep involvement of the US government.

1016 Speech delivered by Coolidge on April 22, 1924, at the Annual Luncheon of the Associated Press in New York, in Hughes to Herrick, April 23, 1924, FRUS: 1924, 2:14. The message was also sent to the American embassies in London, Rome, Berlin, and Brussels. His personal advice for the American delegation was the trademark short form, "Just remember you are Americans." Quoted in Jones, U.S. Diplomats in Europe, 1919-1941, 47. 1017 Hughes's speech at the Pilgrims' Dinner in London, July 21, 1924. Hughes, The Pathway of Peace, 108. 
As another sign of American interest and influence, it was an American demand, and European acquiescence, that this post be filled by an American. Finally, Seymour Parker Gilbert was appointed, who, after a short interim filled by Owen Young, took over the post on October 30, 1924, and resigned six years later. The Agent General for Reparation Payments, as its name indicates, was of a little bit different kind than the controllers in either Austria or Hungary. The emphasis was on the reparation payments, and this key notion gave a bad name to European affairs in the 1920s; American investors, for instance, considered the Reparations Commission a "black beast." 1018 The experts who worked out the details thought that the solution, at least for the time being, was in some kind of reparation payments, if for nothing other than political necessity. France wanted payments, and without it neither Great Britain nor the United States could have been paid back to at least some extent. Benjamin Strong, who was not part of the team working out the details of the plan, thought that it was "a most ingenious plan, if not in fact a masterpiece of ingenuity." ${ }^{1019}$

The $\$ 200$ million loan was to be issued in the fall and the circumstances in its issuance said as much about the American interests on the continent as anything else. As usual, the American tranche of $\$ 110$ million was organized by J. P. Morgan \& Co. Morgan naturally wanted governmental assurance anew for the whole business. Not surprisingly, the mammoth banking house had to face the rigid official line of non-involvement. Secretary of State Hughes only used general terms and gave nonbinding assurances to Dwight Morrow of J. P. Morgan \& Co. in September, when the latter referred to "the heavy responsibility" in case America failed to go ahead with the plan and this fact would cause a breakdown. ${ }^{1020} \mathrm{He}$ informed the other partners that this was "as good as we can expect," and they had to make the most of it. ${ }^{1021}$ Under the surface nonetheless, the American government encouraged the bankers to undertake the loan. ${ }^{1022}$ But the active, albeit non-official, participation of the administration went farther than seeking business support at home. To make sure that parts of the loan would be floated in Europe, the State Department used its influence. When J. P. Morgan \& Co. signaled that they were not willing to float the French loan unless France participated in the Dawes Plan, Hughes agreed with such a view. He further stated that France could count on US State Department support in the

1018 Jones, U.S. Diplomats in Europe, 1919-1941, 19. On the Dawes Plan, also see, Ahamed, Lords of Finance, 197-216.

1019 Quoted in Chandler, Benjamin Strong, 271.

1020 Clarke, Central Bank Cooperation, 55-56.

1021 Morrow to Morgan and Lamont, September 20, 1924, quoted in Costigliola, Awkward Dominion, 124.

1022 Hogan, Informal Entente, 71; Costigliola, "The United States and the Reconstruction of Germany in the 1920s," 493-94. 
pending $\$ 100$ million loan to France only if it agreed with proposed annuities under the Dawes Plan. ${ }^{1023}$ J. P. Morgan \& Co. also did its part in what was a clear case of blackmailing France. The company said that the loan France had been seeking would not be floated unless there was French cooperation. ${ }^{1024}$ Morgan partners used scathing rhetoric when they put the question to France whether they wanted "a rehabilitated Germany" together with American money, or "a broken Germany and what has been called 'security."'1025

The fact that $\$ 110$ million of the total of $\$ 200$ million was raised in America also underscored the fact that this time the United States, even if on unofficial and private level, played a part the importance of which could not be underestimated and misunderstood. Most of the remaining sum of the loan was floated in Great Britain. The two countries thus took $7 / 8^{\text {th }}$ of the total, which was a further proof of the close Anglo-American cooperation. The loan proved to be a huge success and was heavily oversubscribed. The French got their reward for participating: in a few weeks' time, a $\$ 100$ million twenty-five-year loan was floated in the United States. ${ }^{1026}$

The Dawes Plan became effective on September 1, 1924, and for some time it showed signs of success. Thanks to a great injection of American loans in the first place, Germany met its financial obligations almost fully. Next to the financial aspect, soon politically sensitive breakthroughs were attached. For example, In 1925 England, France, Italy, and Germany signed the Treaties of Locarno, which finally established the western borders of Germany and began the withdrawal of occupation forces along the Rhine. As a sign of political reconciliation, Germany was also admitted to the League of Nations in 1926. With the United States taking a huge part in the rebuilding of the German economy, it was finally concluded that America would not let Europe remain a spot of financial and economic chaos. Beyond the private initiative of J. P. Morgan \& Co., there was substantial, albeit unspoken, government support for the scheme. As the Agent General Gilbert put it, the government was "committed [...] as much as it is humanly possible." ${ }^{1027}$ The Dawes Plan and the American loan in connection with it was a landmark case in the relationship between the United States and Europe.

With time however, it became evident that the Dawes Plan could not provide the framework for a lasting solution. Initially money started to pour into Germany, first and foremost from private American sources. In the years following the

1023 Hughes to Herrick (for Logan), November 11, 1924, FRUS: 1924, 2:72-73.

1024 Clarke, Central Bank Cooperation, 68; Lamont, The Ambassador from Wall Street, 203; Marks, "The Myths of Reparations," 248-49.

1025 Quoted in Costigliola, Awkward Dominion, 122.

1026 E. Lamont, The Ambassador from Wall Street, 212.

1027 Gilbert to Morrow, November 26, 1924, quoted in Costigliola, Awkward Dominion, 122. 
launch of the reconstruction program, American investors put up far the biggest part borrowed by German public credit institutions, local governments, and large corporation. Until the end of 1926, out of the 106 external loans 36 were offered in the United States, but in terms of money, out of the nearly $\$ 885$ million, the share of the United States represented almost $\$ 581$ million, or $65.6 \% .^{1028}$ This fresh capital ensured that Germany was able to pay its reparation payment from which the Allies paid back some of their war debts to the United States. But the successful surface hid the harsh reality. The problem was that most of the loans raised for Germany were those of municipalities and states which did not use the money necessarily for productive purposes. The German government was against indiscriminate borrowing of the municipalities, but not having a clear majority in the Reichstag, it was quite powerless in this question. Gilbert and Hjalmar Schacht, president of the Reichsbank, also raised their voices against the indiscriminate borrowings with little avail. ${ }^{1029}$ The German ambassador concluded the harsh reality already at the end of the first year of the Dawes Plan. He stated that "German industry, commerce, agriculture and finance are in a hopeless condition; reparations will never be paid; money loaned to Germany is thrown away [...] I have come to the conclusion that we can do no better service to Germany and to ourselves than to discourage the further placing of German municipal loans in America." ${ }^{1030}$ Although the State Department agreed tacitly, it followed the path of official noninvolvement and assumed no responsibility. ${ }^{1031}$ With almost everybody seeing the problem arising but doing nothing, it was just a question of time when reality had to be faced.

Indeed, once capital had stopped coming, which happened toward the end of the decade, the balance tipped and the payments ceased. The governments involved called for another round of experts' investigation into the problem, again with Americans in the lead. They thought this solution was the only possible remedy. The result was the Young Plan, named after the chairman Owen Young, who already played an influential role in the Dawes Plan. ${ }^{1032}$ This new Plan, introduced in the summer of 1929, aimed at the following: it set the total

1028 Kuzynski, American Loans, 29.

1029 Gilbert concluded in 1927: "These tendencies [overspending and overborrowing], if allowed to continue unchecked, are almost certain [...] to lead to severe economic reaction and depression." Ouoted in Mintz, Deterioration in the Quality of Foreign Bonds, 77. In general see, Policy of the Department of State regarding American Bankers' Loans to German Municipalities, FRUS: 1925, 2:172-87, FRUS: 1926, 2:201-04, and FRUS: 1927, 2:727-30. E. Rosenberg, Financial Missionaries, 171-72.

1030 Schurman to Kellogg, September 15, 1925, FRUS, 1925, Vol. 2, 174. See also his letters to the Secretary of State, September 23, 29, 1925, Ibid., 174-76.

1031 Kellogg to Schurman, October 17, 1925, Ibid., 177-78.

1032 On the efforts of revising the Dawes Plan and about the creation of the Young Plan, see Costigliola, Awkward Dominion, 205-17. 
amount of reparations at 122 billion Reichsmark (\$26 billion); it reduced the annual payment expected from Germany; it introduced a loosened form of Allied control over Germany's economy; and the Bank for International Settlement was set up to handle reparation payments. The Young Plan made the connection between war debts and reparations: any scaling down of the debts would bring about a corresponding reduction in reparations. The Plan, whatever its worth, worked for some time, but in 1931 the world crisis made its presence felt and drastic changes had to be introduced. Hoover's attempt to alleviate the problem in the form of a year-long moratorium on paying intergovernmental debts did not bear fruit. ${ }^{1033}$ Finally, as a result of the Lausanne Conference in 1932, 90\% of the reparations due under the Plan was cancelled. In addition, basically all reparation payments were cancelled, and Hungary also achieved a goal it set out to do earlier. But the joy, if any, over that achievement was short-lived, because the world crisis made life much more difficult for every country to get by.

Poland was in many ways in an exceptional situation. Soon after the end of World War I, it fought a short war against Soviet Russia in 1920. Its location signified the importance of the country. It was seen in the West as a defense line against Communism possibly spreading from its Bolshevik eastern neighbor. Therefore, the political, financial, and economic stability of the country was of immense importance. Although Poland did not have to pay reparations, by the end of 1923, the currency showed dangerous depreciation. ${ }^{1034}$ In 1923 , there were British advisers, but one of them, Frank Horsfall Nixon, made it clear that Poland would not accept a League intervention. ${ }^{1035}$ The main reason for this was that Polish leaders did not wish to place their country under British influence. The Poles, similarly to other countries in the region, looked to the United States as the only possible country to bring peace and prosperity, and to ensure safety against either the Soviet or German threat. In turn, Benjamin Strong was of the opinion that in the case of Poland, some other plan should be found than the League of Nations scheme in Austria and Hungary. ${ }^{1036}$

Accordingly, the Poles secured Edwin Kemmerer for financial adviser, who spent a few days at the turn of 1925 and 1926 in Poland, and later returned for a longer period during the next summer. The coup led by the nationalist Jozef

1033 President Herbert Hoover's sudden proposal for a one-year moratorium commencing July 1, 1931, on all intergovernmental debts, can be found in FRUS: 1931 (Washington, DC: Government Printing Office, 1946), 1:33-35. The idea of the Hoover moratorium came from Russel Leffingwel, and it was largely due to Lamont's persuasion that Hoover accepted it. Lamont, The Ambassador form Wall Street, 294-96. On the Moratorium, which Hoover wrote of as his own idea, see Hoover, Memoirs, vo. 3, 67-72.

1034 Lojkó, Meddling in Middle Europe, 311.

1035 Orde, British Policy and European Reconstruction, 277.

1036 Meyer, Bankers' Diplomacy, 72. 
Pilsudski in the spring of 1926 brought a halt to any negotiations, but finally, in the summer of 1927, based upon Kemmerer's second study, the Polish plan of stabilization was born, "a man size job and a perpetual one."1037 Poland would get a credit of $\$ 20$ million for one year, in which 14 central banks took part with a conspicuous American lead. The Federal Reserve Bank of New York provided \$5,250,000; Great Britain, Germany, and France each gave \$3 million; while Austria and Hungary were on the list with $\$ 500,000$ each. ${ }^{1038}$ The heavy American involvement may have had a political underpinning as well. The American minister to Poland wrote that lack of American money threatened "the turning of the country to Bolshevism, thereby breaking down the wall between the [U]SSR and the rest of Europe."1039 Poland was to secure a $\$ 60$ million loan and accept that a foreign adviser should be appointed to the Bank of Poland. ${ }^{1040}$ In October 1927, a loan of $\$ 72$ million was finally raised in seven countries. More than half of it, $\$ 47$ million was issued in New York, while $£ 2$ million (\$9 million) was issued in London. ${ }^{1041}$ It was the first case that Strong and not Norman had played the leading role in a European financial reconstruction. The interest rate was $7 \%$; the price of issue was $92 .{ }^{1042}$ Out of the $\$ 72$ million, only 15 million was spent on currency stabilization, and the stabilization of Polish economy did not really take place. ${ }^{1043}$ The 1929 crisis changed the whole landscape and Poland found itself in trouble like all the other countries. Still, it did not default on its loan and until 1936 it made full payment, later on only partial one.

The fierce antagonism on the part of Poland toward foreign control is a good example of a wider phenomenon. Poland embodied the majority of the countries in the sense that they did not want control. If anything, they were willing to subject themselves to a much looser kind of supervision under fellow central banks. In the beginning and in the most sensitive countries, the League of Nations, or the countries involved in a loan, was adamant on the point of control. In fact, it was one of the key issues. After the Austrian, Hungarian, and German stabilization efforts seemed to achieve the desired results, the political necessity was not there anymore to demand a strict supervision. It was thought instead

1037 Kemmerer to William Hard, April 28, 1926, Folder 8, Poland, Correspondence G-L, 1926-1927, Box 209, Kemmerer Papers; Meyer, Bankers' Diplomacy, 65.

1038 lbid., 87.

1039 Stetson to Kellogg, May 10, 1926, Quoted in U.S. Diplomats in Europe, 67. Stetton was a sharp observer. He wrote to the Secretary of States that "All money which comes to Europe turns at once into political force [...] Therefore, whether we admit or not, we are participating in European politics." Stetson to Kellogg, May 10, 1926, quoted in Ibid., 68.

1040 Chandler, Benjamin Strong, 401-402.

1041 Meyer, Bankers' Diplomacy, 90.

1042 Meyer, Bankers' Diplomacy, 89.

1043 Frank Costigliola, "American Foreign Policy in the 'Nut Cracker': The United States and Poland in the 1920s," The Pacific Historical Review 48 (February 1979): 102. 
that along pure financial lines, and the inherently built-in control through the usually newly set up central banks, the loan business would work more or less automatically. Although the Great Depression and the world crisis in its wake changed everything, it still looks debatable that the idea was inherently sound. These central and eastern European countries historically lacked what was the financial norm in the West and they could not function prosperously without the presence of strict control. But from a political point of view, exactly that kind of strict supervision was impossible to install. In a Catch-22, everyone was a loser, which fact loomed large in the many defaults and nervous attempts to arrange some kind of transfers from the early 1930s. Jeremiah Smith, Jr. was right: somewhere something surely went wrong,

\subsection{The Three American Financial Controllers in Europe in the 1920s}

The three American financial controllers, or advisers, show an interesting imprint in the United States' both official and unofficial attitude toward Central Europe. The persons in question, Jeremiah Smith, Jr., Seymour Parker Gilbert, and Charles Dewey, in chronological order, fulfilled very similar posts with similar functions. This statement is especially true for the first two of the trio, who both commenced their work in 1924, and in both cases the reconstruction schemes were similar. They were supposed to watch the investors' interests and in order to be able to function in such capacity they were entitled to control the finances of the target countries in order to insure that the planned reforms would be carried out and the governments would not use the monies for unproductive purposes. Obviously, to a differing extent, they were the means of broader political considerations. They showed what limited commitment the United States was willing to take in order to ensure the financial stabilization of the Central European region. Beyond this well-hidden interest lied an immense stake for the United States in Germany. No wonder that out of the three countries, this was the place where the American involvement was the biggest. Despite the fact that an official coming from the United States enjoyed immense prestige in the mentioned region, their statuses, however, were very different in each case.

The first of these three Americans, Jeremiah Smith, Jr., was in the "most comfortable" situation. He was the first chronologically, but most importantly, he was functioning under the League of Nations, which made a lot of difference. He was not chosen by the State Department, because the American government did not wish to be involved in a League undertaking, and, consequently, he did not serve direct US governmental interests. Still, it was well for the Coolidge administration that an American was selected, since an American citizen, even 
in his private capacity, did represent the United States and, in a fortunate case, managed to spread the values and philosophies of what America stood for. Also, by virtue of a loan under the strict rules by the League of Nations, it was basically guaranteed that the Hungarian government would cooperate with Smith. It was in their best interest to do so: they viewed the loan as the ticket into the international financial arena where the conspicuous strength of private American investors was impossible to miss. Performing well under an American was thought to give the green light for future American investments. It is obvious that it was not the nationality of the person that made the difference whether American capital would come or not but the financial situation and performance of the country. Still, it is undeniable that the good news coming from a compatriot made the American bankers more willing when it came to deciding about a Hungarian loan. The great hope of American capital also started to materialize and between 1924 and 1928 it was a total of $\$ 115,150,000$, therefore the expectations of having. ${ }^{1044}$ In addition, Smith's personality was perfect for cooperation, understanding, and pragmatic flexibility. His status as a friendly adviser, as he liked to see himself, bore fruit in the relation between him and both the Hungarian government and the population at large. Therefore, it is safe to say that an American controller paid off. It managed to qualm political whims, it worked in the practical and professional American style, it functioned as a smooth conduit between Hungary and the League of Nations, and the American capital started to come into the country as well. The farewell from Jeremiah Smith, Jr. meant for Hungary the end of the explicit League control, and it was all up to Hungary how it managed its household

Contrary to Smith, Seymour Parker Gilbert was the epitome of the postwar American attitude toward Europe. Only a few months after Smith began his work in Budapest, Gilbert was chosen for the most influential financial post in postwar Europe. His selection as the Agent General for Reparations Payments showed certain important features. ${ }^{1045}$ First of all, the person had to be an American, since most of the money was coming from the United States. ${ }^{1046}$ Secondly, the very fact that Gilbert was a consensus choice of the government and big business shows that in the case of Germany the United States went farther than

1044 Péteri, Revolutionary Twenties, 180.

1045 The first candidate was Logan, but J. P. Morgan \& Co. was against him and wanted Dwight W. Morrow for the job. The administration was not enthusiastic about him and he refused on personal grounds. Finally, Gilbert was selected. In more detail about the problems surrounding his nomination, see FRUS: 1924, 2:135-39; Kenneth Paul Jones, "Discord and Collaboration: Choosing an Agent General for Reparations," Diplomatic History 1 (Spring 1977): 118-39.

1046 "There was unanimous desire, with Governments also agreeing, for appointment of an American as Agent General." C Myron T. Herrick (Logan) to Hughes, July 2, 1924, FRUS: $1924,2: 136$. 
in any other country toward making sure that events would unfold according to its taste. This was the most spectacular example of how important Germany was for the US government. Since the Dawes Plan was not a League effort but cooperation with American leadership, the Coolidge administration had a very large interest in having the Agent General represent the American interests well. This was also the goal of J. P. Morgan \& Co. from the investment point of view. They needed a person to watch over the Germans in case they did not play by the rules. Moreover, the Agent General had to be strong to resist possible outside pressure from Great Britain, but most importantly from France. Finally, the choice of Gilbert shows the governmental efforts: he stepped down in the fall of 1923 as Under Secretary of the Treasury. The unofficial representation by a former government employee cannot be read differently than unsaid commitment on the part of the US government. Consequently, through his filling the post in Germany, the Coolidge administration did manage to send its own man. Naturally, the US government wanted to remain officially aloof and the official line was as uncommitted as ever. As the Secretary of State put it to the President, "there is no objection here to this appointment provided the suggestion comes in the proper way from the Governments represented on the Reparations Commission and has the approval of Germany." ${ }^{1047}$ This was vintage US postwar attitude toward the European problem: to depoliticize the issue, not to take responsibility, though still wishing to take the lead and dictate conditions. Despite Gilbert's unofficial status, nobody could doubt that he had relations to the administration, which he indeed did.

Obviously, it was of crucial significance who filled the all-important post. The main problem with Gilbert was that of his age, a tender 32. Although he was appointed under secretary at the age of 28 , ran the department in the absence of Secretary Mellon, and was called a "thinking machine," the hosts were not very much keen on him. ${ }^{1048}$ The Germans in particular were of the opinion that such a young man would not be able to carry out the task at hand. He had to try to keep a balance between what Germany was able to pay and a scenario that lead to no danger of financial instability. The whiz kid did try his best but the whole plan, with the office and the performance of the Agent General, was not promising right from the start. In addition, Gilbert was not an easy person and he stayed aloof from Germany in general. He did not learn to speak German in six years, nor did he socialize with Germans. This in itself would have been not a real problem. But owing to his mumbling way of speaking, he was oftentimes not understandable even to his own countrymen. ${ }^{1049}$

1047 Hughes to Coolidge, August 16, 1924, FRUS: 1924, 2:138.

1048 Chernow, The House of Morgan, 253.

1049 lbid. 
Despite his best efforts, Gilbert's work did not amount to a success story. With time, it became evident that the Dawes Plan could not provide the framework for a lasting solution. Notwithstanding a massive injection of money in the shape of loans, the German economy could not climb out of its hole and indiscriminate borrowing was a pastime among German municipalities. Gilbert raised his voice against the indiscriminate borrowings with little avail. ${ }^{1050}$ Therefore, on both accounts, professionally and humanly, Gilbert did not measure up to Smith.

In the case of Poland, any financial adviser would have found himself in no easy situation. The last example of an American adviser to a Central European country in the 1920s was a strange mixture at best in the end. It was a political necessity for Poland to try to rehabilitate the country with American help and not through the League of Nations, so the financial adviser also had to be an American. However, the high nationalistic feeling and pride of the country made it impossible for a strict control of the finances. Edwin Kemmerer, who paid two well-paid visits to Poland as an adviser in his famous "money doctor" glory, informed Strong that "the prospects look good that we may be able to accomplish something worth while." ${ }^{1051}$ But for the actual post of advising the Poles, Charles Schuveldt Dewey was selected, also a former banker and Assistant Secretary of the US Treasury, by the effective involvement of Strong. ${ }^{1052}$ Dewey asked for Kemmerer's help in getting information about a place the "doctor" had visited, and was also looking for any suggestion as to whom he should take with him as an assistant. ${ }^{1053}$ Dewey was not as warmly received as Kemmerer. While the Polish government was happy to pay Kemmerer $\$ 10,000$ and expenses for his services, in the case of Dewey, they expected him to pay his assistant from his own salary. ${ }^{1054}$

Dewey had relatively a wide circle of powers to protect the bond holders, but as far as general control over the monetary issues of Poland were concerned, his powers were much more limited than those of either Smith's or Gilbert's. The

1050 Gilbert concluded in 1927: "These tendencies [overspending and overborrowing], if allowed to continue unchecked, are almost certain... to lead to severe economic reaction and depression." Quoted in Mintz, Deterioration in the Quality of Foreign Bonds, 77. In general, see, Policy of the Department of State regarding American Bankers' Loans to German Municipalities, FRUS: 1925, 2:172-87, FRUS: 1926, 2:201-04, and FRUS: 1927 2:727-30; E. Rosenberg, Financial Missionaries, 171-72.

1051 Kemmerer to Strong, July 14, 1926, Folder 5, Strong, Benjamin, 1916-1928, Box 16, Kemmerer Papers.

1052 Chandler, Benjamin Strong, 402.

1053 Dewey to Kemmerer, October 3, 1927, Folder 4, Correspondence, 1927 October 1928 January, A - D, Box 40, Kemmerer Papers.

1054 Diary entry, December 17, 1925, Folder 2, Diaries of Edwin Kemmerer - Poland, April 30, 1925 - September 18, 1926, Box 293, Kemmerer Papers; Dewey to Kemmerer, October 3, 1927, Folder 4, Correspondence, October 1927 - January 1928, A - D, Box 40, Kemmerer Papers. 
main reason for this was that there was no international body behind him as in the case of Zimmerman or Smith. ${ }^{1055}$ In contrast to his peers in Austria, Hungary, and Germany, he had little real power over how the Polish finance ministry was working. The British were angry at the lack of real control. Frederick Leith-Ross of the Reparations Commission said it was like "trying to reform a harlot by providing her with funds against a promise of chastity." ${ }^{1056} \mathrm{His}$ role was rather to insure that further loans would come to Poland.

The similarity between his and Gilbert's posts cannot be missed. He claimed later in his life that it was Secretary of Treasury Mellon who appointed him for the post, which seems to refute the suggestion that he was a pick by the bankers. ${ }^{1057}$ Poland was a sensitive country for the United States, if for nothing else but for its close geographical proximity to the Soviet Union. However, in this case the US government never worried about the fact that the Poles viewed Dewey only as the key to further American loans, and they made no secret about it. As excerpts from two letters make it clear, the Adviser was a paper tiger at best:

I express my wish that the Adviser should abstain from reading Polish and German newspapers [...] In this way, the Adviser would avoid poor and erroneous information, the correction of which would take all of the government's time without leaving it a minute of rest after its work. Furthermore, I desire that the Adviser should endeavor to avoid mixing in any manner whatever in the internal affairs of the State by undertaking to defend any party or group, and that he should be careful, in the economic and financial area, never to put himself in opposition to the Minister of Finance and the President of the Cabinet. ${ }^{1058}$

Ciechanoswski, Polish Minister to the US, also informed the Adviser-designate Dewey about such wishes. He informed him that "whatever analogy may actually exist between your work as Adviser in Poland and such activities as those of Mr. S Parker Gilbert in Germany, or Jeremiah Smith in Hungary, I consider it is important for you to avoid stressing any such analogy." ${ }^{1059}$ Possibly, his only tool of control would have been his reports on the financial and economic situation due every three months. These, however, were means of a pseudo control. If he painted a negative picture, the credit of Poland would have suffered, and consequently, the

1055 Meyer, Bankers' Diplomacy, 83.

1056 Leith-Ross to Niemeyer, June 7, 1927, quoted in Costigliola, "American Foreign Policy," 104.

1057 E. Rosenberg, Financial Missionaries, 181.

1058 Letter to the bankers signed by Pilsudski, October 13, 1927, quoted in Meyer, Bankers' Diplomacy, 90-91.

1059 Ciechanowski to Dewey, November 5, 1927, quoted in Ibid., 91. 
goal toward which Dewey was working, that is, the stabilization of the country, would have been endangered. Therefore, Dewey tried to create an optimistic impression in his reports, which behavior also spared him confrontations with the Polish officials and the public in general. His low status in Poland, in a sharp contrast to his nationality and connections to the government, was well tangible in his nickname by his host country. He was called Dawaj (hand it over!), which indicated that the only role he really was thought of playing was to make sure that foreign capital would come to Poland. ${ }^{1060}$ When soon after the initial success, the Polish bonds showed a sharp decline and Poland could not secure much more money, the reputation and integrity of Dewey experienced a similar drop.

Unlike Jeremiah Smith, Jr., neither Gilbert nor Dewey managed to strike an honestly friendly chord with their host countries. Both latter persons were looked at suspicion and impatience, while they too did not make every effort on their part to be better understood and accepted either. Simply, they were inadequate to meet the social challenge inherent in their job. In a sharp contrast to both, Smith was a real favorite in Hungary. Although his job might have been facilitated by a more cooperative government that did not dare to challenge the League of Nations, which would have been very counterproductive from every point of view, the popularity he achieved cannot be explained by this mere fact. Aside from his luck that he served at the best time when overborrowing had not reared its ugly head yet, and the Austrian League scheme was serving as a very useful springboard, still, Smith's personality was a key factor in his work and success. He did not represent his government; he had no governmental connections. He did work for the League of Nations, an international body he had faith in for the political future of Europe and the world at large. But most importantly, he did everything in his capacity to serve Hungary and the Hungarian people, who were very grateful for such open and modest magnanimity.

1060 E. Rosenberg, Financial Missionaries, 182. 